\title{
The Solidarity Days: A short reminiscence
}

\section{NICOLAS ROTHWELL}

With the retrospect of two decades, the denouement of the Solidarity saga and the revolutionary tide that swept across the face of Central Europe now seem dusted by a deceptive sheen of inevitability. But for those plunged in the hurtling cascade of events that made up 1989, the memory is rather different. The participants, the witnesses and the manipulators behind the scenes did not know where history was going, or how the river flow of events would spill across the terrain of social life, until the landscape reached, at last, a new conformation of stability. How hard it is, in the early years of the twenty-first century, with our present knowledge of the vast consequences born of the slight shifts in the political balance at the outset of 1989, to recall the specific tone and quality of those days. They were uncertain, they were drenched in uncertainty; in the cities of the Warsaw Pact, mantled by their constant coat of brown coal fumes and industrial smog, slender hopes and fine ideals were all that kept the heart alive.

What did we who were visitors from outside the system see? Can we recapture our feelings and convictions then? We did not know what was going to happen, or how, or how far things would go; but there was a sense in the air, at the outset of the year of transformations, that history, after a long slumber, was starting up again. This resumption had been prepared by the preceding decade: the Solidarity years in Poland, above all, which was a period of moral rebirth. My own experience of Poland in the late 1980s left me greatly changed; I had a sense, for the first time in my life, of the power of ideas and the reality of national convictions. I also had a new sense of the way different factors, even conflicting factors, fit together in the march of history, and produce, by their clash and by the negotiation of their various intertwining influences, outcomes quite distinct from those intended by the principals in the drama.

If we glance back now at a thematic x-ray of 1989, it is plain that four central figures helped shape the climate. First was Ronald Reagan, a president with very clear-cut ideas about communism; his actions while in office brought the Soviet 
Union to the negotiating table; his military build-up precipitated the Moscow regime's financial crisis. Reagan's Vice-President and successor, the cautious, quietist George Bush, then through masterful inaction allowed the cavalcade of change in Europe's heart to rush ahead in its natural rhythm. The second key actor onstage was the Polish Pope, John Paul II, whose insistent message to his people, and to the people of all the shadowed half of Europe, led them to lift up their eyes and to preserve a small flame of hope in their hearts. Lech Wałęsa, who by this stage had come to incarnate Poland's demands for profound reform, was the natural counter to the Warsaw government. But by sublime paradox, the worst enemy of the European status quo was the leader of the Eastern Bloc, Mikhail Gorbachev, who, at every key turn in the course of 1989, was on hand, insisting that the time for force and constraint to hold the Soviet satellite empire intact was gone. All of these actors were necessary figures in the transformation. None of them expected the year of revolutions to end as it did; all of them, in their respective ways, exerted their will to break the system. Each one of the four was a man on a grander scale than the times; their mutual interaction in the course of the whole decade leading up to 1989 did much to ensure that confrontation found release, and that a dark interval of stagnation in European history came to a startling end.

It is this quality of surprise that seems most worth dwelling on today. Not one correspondent predicted in serious fashion the outcome of the chain of events we all witnessed. Not one politician knew the script. Not one commentator or pundit, with the exception, oddly, of Polish émigré Zbigniew Brzezinski, dared envision the collapse in that year of the Berlin Wall. But there was a strong consciousness that something new was alive in Central European affairs. It had been inaugurated by the initial surge of defiance in Poland in the early 1980s, and distilled further by the bitter disappointment of the martial law era and the regime of compromise put in place under Jaruzelski. I remember with great clarity the sense I had, moving across Poland in the late 1980s, that almost everyone, from whatever region or age or class, shared the same broad aspiration: for a normal country, for freedom - a concept understood without any postmodern ironies in those days. I could describe in detail the chain of chance experiences that left me with this impression - an impression as strong and all-suffusing as the gleam of anticipatory light that comes as harbinger long before the dawn breaks across the sky. That gathering sense of revival itself did much to shape the course of events. It was Poland - the European nation-state with the most protracted history of suffering - that provided the potentiating example for the region; similar currents of moral and cultural revival gained strength throughout the bloc. But this renaissance of spirit was a humble, tentative thing; it was expressed in dingy cafes and student rooms, in meetings and rallies under pressure, in the columns of leaflets and grainy unofficial publications. In its Polish avatar, it was very strongly connected with a sense of 
the nation as a hearth of culture; indeed, of Poland not just in its familiar role as Christian martyr country, but as an outpost of Western rights and values, as a banner carrier of civilisation, contending against the oppressive, sombre forces of the Soviet system - opposed forces that were seen as the epitome of the rough, the barbaric and the uncivilised. Everyday life was itself a key stage for this drama, a part of the battlefield. Thus, in the early months of 1989, there was a distinct return to old-fashioned ways of being. 'Comrade' was out; the Polish equivalents of sir and madam were in. Churches were full; museums and concert houses and contemporary art spaces, too. The words of the dissident intellectual were as greatly prized as the acts of the dissident worker. The slogans of Solidarity seemed to transmute into an extended demand for dignity and truth. The overviews of Polish life and consciousness I had in those daysplunged into reformist circles linked to the Jagiellonian University in Krakówwere naturally somewhat removed from the social norm in other parts of the country, but I travelled sufficiently widely to catch the atmosphere. When courtly, serious figures such as Bronisław Geremek or Tadeusz Mazowiecki came onto the national stage, the pride Polish men and women from factory towns and peasant villages felt in them was palpable. One had the extraordinary sense of moving across the face of the country and seeing its old core and essence come back to life. Those experiences were enough to make clear that the stream of national culture the communist regime had sought to destroy had not even been successfully interrupted; it had merely been submerged, and now it was resurfacing, and shaping the present day.

The transformation in Poland had its political stages, of course: the round table, the elections, the coalition-making process. But the political dimension was secondary; the moral climate had been transformed by the four factors that the radical figures of the 1980s drama incarnated: national will, which Lech Wałęsa brought with him to the table; Western determination, as represented by the American administration of the era; an awareness of spiritual belief, which was the gift of the Polish Pope; and the arrival of an idealist at the pinnacle of the Kremlin. This constellation of circumstances made possible the carnival of liberation that played out before the eyes of bemused witnesses that year. Everyone who saw these things knew it was a golden time. No-one dared believe how far the change would go. It is a measure of the period's extraordinary intensity that it cannot be easily recaptured or conveyed in words today. An air of natural progression seems part of the tale of 1989 now: month following smoothly after month in the hazy glow of retrospect. But the experience was different; each day, we watched, and saw the best outcomes, schooled though we were to detect the worst. 